\title{
ELEKTRONICKÝ PODPIS A MOŽNOSTI JEHO VYUŽITIA - ANALÝZA VYUŽÍVANIA ELEKTRONICKÉHO PODPISU V SLOVENSKEJ REPUBLIKE
}

\author{
Juraj Fabuš*
}

\section{Úvod}

Séria článkov vzniká za účelom analýzy využívania elektronického podpisu v Slovenskej republike. Hlavnou témou tohto článku je analýza využívania elektronického podpisu v Slovenskej republike. Jedná sa o druhý článok série.

Zverejnenie práce bolo z dôvodu obšírnosti problematiky rozdelené do viacerých článkov, ktoré budú postupne publikované v tomto elektronickom časopise. V nasledujúcej, poslednej časti, budú identifikované perspektívne oblasti jeho využívania.

Ciel'om je zvýšit' povedomie o elektronickom podpise, zvýšit' záujem o jeho využívanie, ako aj opísat' okolnosti potrebné pre zavedenie elektronických volieb. Články sú určené všetkým, ktorí elektronický podpis už využívajú, ale aj pre tých, ktorí sa s ním ešte len zoznamujú.

\section{Súčasný stav a perspektívy}

V súčasnom období je na Slovensku odvetvie informačných a komunikačných technológií ovplyvnené krízou, podobne ako ostatné odvetvia priemyslu. Podl'a rôznych analýz bude najbližšie obdobie charakterizované spomalením rastu priemyslu informačných a komunikačných technológií (IKT) v dôsledku spôsobenej prehlbujúcej sa kríze svetového hospodárstva a poklesu istoty na strane zákazníkov a podnikatel'ov. Na druhej strane sú však oblasti, ktoré kríza zasiahne v menšej miere, ako napríklad vývoj softvéru a služby v oblasti IKT. Zo strany vlády SR bude investície do oblasti IKT v období do roku 2013 výrazne podporovat' implementácia operačného programu Informatizácia spoločnosti ako aj d'alšie operačné programy, kde je horizontálnou prioritou informačná spoločnost'. [1]

Pozitívnou skutočnost'ou je fakt, že vo využívaní elektronických služieb občanmi a podnikatel'mi je SR nad priemerom úrovne EÚ a zároveň patrí ku krajinám s najvyšším percentom využívania týchto služieb podnikatel'mi. V súvislosti s dôsledkami hospodárskej krízy a s nimi súvisiacimi obmedzeniami štátneho rozpočtu tiež významnou mierou rastie potreba koordinovaného vládneho prístupu voblasti informatizácie spoločnosti. Bude potrebné intenzívne pokračovat' v integrácii IKT politík do štátnych stratégií (najmä v oblasti

\footnotetext{
${ }^{*}$ Ing. Juraj Fabuš, PhD., Žilinská univerzita v Žiline, Fakulta prevádzky a ekonomiky dopravy a spojov, Katedra Spojov, Univerzitná 1, 01026 Žilina, Slovenská republika, tel.: +421 908171 890, E-mail:

juraj.fabus@fpedas.uniza.sk
} 
vzdelávania, zdravotnej starostlivosti, zvyšovania energetickej účinnosti, sociálnej inklúzie) s ciel'om zlepšit' hospodársky rast, zamestnanost' a sociálne blaho. V prípade Slovenska to znamená podporit' najmä investície do rozvoja l'udského kapitálu a vedomostnej spoločnosti, čo zahŕňa najmä oblasti vzdelávania, vedy, výskumu a inovácií, elektronickej verejnej správy a zavádzania širokopásmového prístupu. [1]

\section{Elektronická verejná správa}

Ciel'om stratégie informatizácie spoločnosti v oblasti elektronickej verejnej správy je poskytovat' dobre zorganizované služby a dosiahnut' stav jej efektívneho fungovania, kedy zber, využitie, správa a poskytovanie údajov prebieha transparentným, bezpečným a uživatel'sky priatel'ským spôsobom; verejné služby sú dostupné viacerými elektronickými kanálmi (napr. prostredníctvom internetu, mobilného telefónu, digitálnej televízie) a zároveň sú v širokej miere využívané. Informačné a komunikačné technológie by mali byt' prostriedkom, ktorý rozšíri možnosti prístupu užívatel'ov k verejným službám, pričom možnost' poskytovania služieb prostredníctvom osobného kontaktu ostane zachovaná pre všetkých, ktorí z rôznych dôvodov nie sú schopní alebo ochotní využit' elektronické prostriedky. Prostredníctvom legislatívnych opatrení, transformácie a zjednodušení procesov vo verejnej správe je potrebné prispiet' k odstráneniu bariér, ktoré negatívne ovplyvňujú využívanie elektronických služieb verejnej správy občanmi a podnikatel'mi. V tomto zmysle môže byt' užitočné poučit' sa zo skúseností krajín, ktoré napriek tomu, že sú na popredných miestach v poskytovaní elektronických služieb verejnej správy, čelia nízkemu záujmu o tieto služby zo strany občanov. Aplikáciou najlepších skúseností z krajín, v ktorých sú elektronické služby verejnej správy široko využívané a intenzívnej priebežnej osvetovej kampane je potrebné podporit' využívanie a rozširovanie elektronických služieb verejnej správy. Zároveň bude potrebné podporit' l'ahšiu dostupnost' služby zaručeného elektronického podpisu pre občanov a dbat' na jeho vyžadovanie pre elektronické služby verejnej správy len v opodstatnených prípadoch, v súlade s trendom znižovania administratívnej náročnosti.

Miestna samospráva, tým že pre mnoho občanov predstavuje hlavnú skúsenost's verejnou správou, zohráva v procese elektronizácie služieb verejnej správy mimoriadne významnú úlohu. V dôsledku pomerne vel'kého množstva originálnych, aj zo štátu prenesených kompetencií, ponúka občanom širokú škálu služieb. Úroveň nasadzovania elektronických služieb je však nejednotná a okrem dostupnosti finančných zdrojov ju ovplyvňuje najmä regionálna lokalizácia a vel'kostná kategória miest a obcí. Zatial' čo sprístupňovanie informácií prostredníctvom web stránok sa stáva bežnou praxou, oblast' nasadzovania elektronických služieb pre miestne samosprávy je potrebné podporit'.

Východiskom pre implementáciu elektronickej verejnej správy na Slovensku sú dokumenty Stratégia informatizácie verejnej správy a Národná koncepcia informatizácie verejnej správy schválené vládou SR v roku 2008. Stratégia informatizácie verejnej správy, ponúka víziu eGovernment-u v Slovenskej republike do roku 2013. Dodržiavanie jednotných štandardov pre informačné systémy verejnej správy, ako aj dodržiavanie princípov interoperability informačných systémov vytvorí základ eGovernmentu a komunikačno-technologickú infraštruktúru verejnej správy, ktorá zabezpečí efektívne a jednoduché prepájanie informačných systémov jednotlivých úsekov verejnej správy na úrovni štátnej správy aj samosprávy. 


\section{Colné riaditel'stvo}

Od prvého júla 2009 prešlo celé colné konanie a tým i vývoz tovarov zo Slovenska podl'a spoločných pravidiel Európskej únie z papierovej formy do počítačov. Približne tri tisícky slovenských exportérov podáva od tohto dňa colné vyhlásenia už len elektronicky a celý proces vývozného konania sa sleduje len cez internet.

Do pilotnej prevádzky od marca 2009 sa najprv zapojili len dobrovol’níci, ale drvivá väčšina podnikatel'ov sa musela do tohto termínu vyrovnat's technicko-administratívnymi procedúrami, ktoré boli náročné len do okamihu nábehu na využívanie softvéru a automatický pohyb tovaru cez hranice. Nový vývozný systém cez internet nielen zjednodušil, zrýchlil a skoordinoval na území Spoločenstva colné konanie, ale podstatne znížil aj náklady Colného riaditel'stva SR. Európskym, čiže i našim firmám sa tak podniká l'ahšie a polepšili si tým aj v globálnej konkurencii. [2]

Spustením prevádzky novej elektronickej podatel'ne Colného riaditel'stva SR od 15. februára 2010 došlo ku zmenám v pravidlách komunikácie. Najvýznamnejšou zmenou je zabezpečenie elektronickej komunikácie medzi používatel'mi elektronických služieb a colnou správou priamo, bez využitia služieb certifikovaného operátora.

\section{Kataster nehnutel'ností}

S účinnost'ou od 1. septembra 2009 sa novelizoval katastrálny zákon, pričom novela okrem iných zmien priniesla i možnost' katastrálneho konania v elektronickej podobe.

Ak všetci účastníci zmluvného kontraktu disponujú zaručeným elektronickým podpisom a časovou pečiatkou, tak elektronické konanie vo vzt'ahu ku katastru je bezproblémové. Právna úprava predpokladá práve takýto spôsob elektronickej komunikácie. Takáto situácia je však v praxi málo pravdepodobná, pretože „bežný" človek sa bude asi len t’ažko zaoberat' problematiku zaručeného elektronického podpisu, nehovoriac o jeho financovaní, iba kvôli tomu, že chce jednorazovo podat' návrh na vklad do katastra. Skôr sa budú za účelom zníženia správnych poplatkov objavovat' elektronické návrhy podané prostredníctvom tretích osôb (notári, advokáti, realitné spoločnosti), ktoré takýmto spôsobom získavajú konkurenčnú výhodu. [3]

\section{Súdny systém}

Ministerstvo Slovenskej republiky umožňuje elektronické podávanie žalobných návrhov a iných podaní za predpokladu ich opatrenia zaručeným elektronickým podpisom. Takéto podania nemusíme už dopíňat' $\mathrm{v}$ papierovej podobe. $\mathrm{Na}$ súdoch sa zriadila elektronická podatel’ňa, ktorá automaticky vygeneruje potvrdenku s presným časom prijatia podania, ktorú elektronicky odošle odosielatel'ovi. Potvrdenka podpísaná zaručeným elektronickým podpisom súdu predstavuje dôkazný prostriedok, vd’aka ktorému nezmeškáte procesnú lehotu.

Pri klasickom styku musíme žalobu spolu s prílohami zasielat' na súd vo viacerých vyhotoveniach. Pri elektronickom styku táto povinnost' logicky odpadá. Prílohy k žalobnému návrhu sa digitalizujú, pričom súd zabezpečí ich vytlačenie a vyhotovenie potrebného počtu fotokópii bez náhrady ich vecných nákladov. Digitalizácia tak minimalizuje aj náklady na papierové dokumenty. Súdne listiny prichádzajú $\mathrm{v}$ elektronickej podobe, nemusíme tak 
zbytočne skladovat' vel'ké množstvá papiera. Pohodlie, úspora času, peňazí a flexibilita komunikácie, sa tak ako pri obchodnom registri, naplno prejavujú i pri elektronickej komunikácii so súdom. [4]

Pokial' sa žalujúci zaregistruje na portáli, systém eviduje jeho údaje, takže v prípade d'alšej žaloby stačí vyplnit' už iba čast' údajov. V súčasnosti tiež portál umožňuje existujúcu žalobu doložit', čo znamená, že k prebiehajúcemu konaniu je možné podat' podnet, alebo niečo doložit' aj elektronicky. Potrebné je zadat' údaje, podl'a ktorých sa dá prebiehajúci spor identifikovat'. Ked’že každá žaloba sa podpisuje zaručeným elektronickým podpisom, je zaručená aj autenticita odosielatel’a správy. [5]

Aj napriek tomu, že v rámci eGovernment-u už fungujú niektoré elektronické služby a projekty, riešenie portálu „eŽalôb“ je prvým komplexným riešením v tejto oblasti. Okrem jasne definovanej štruktúry celého procesu riešenie podporuje aj reálne využitie elektronického podpisu v praxi. Spracovanie žalôb prostredníctvom portálu je prehl'adné a neovplyvnitel'né. Zefektívňuje prácu nielen štátnym úradníkom, ale aj občanom a firmám. [4]

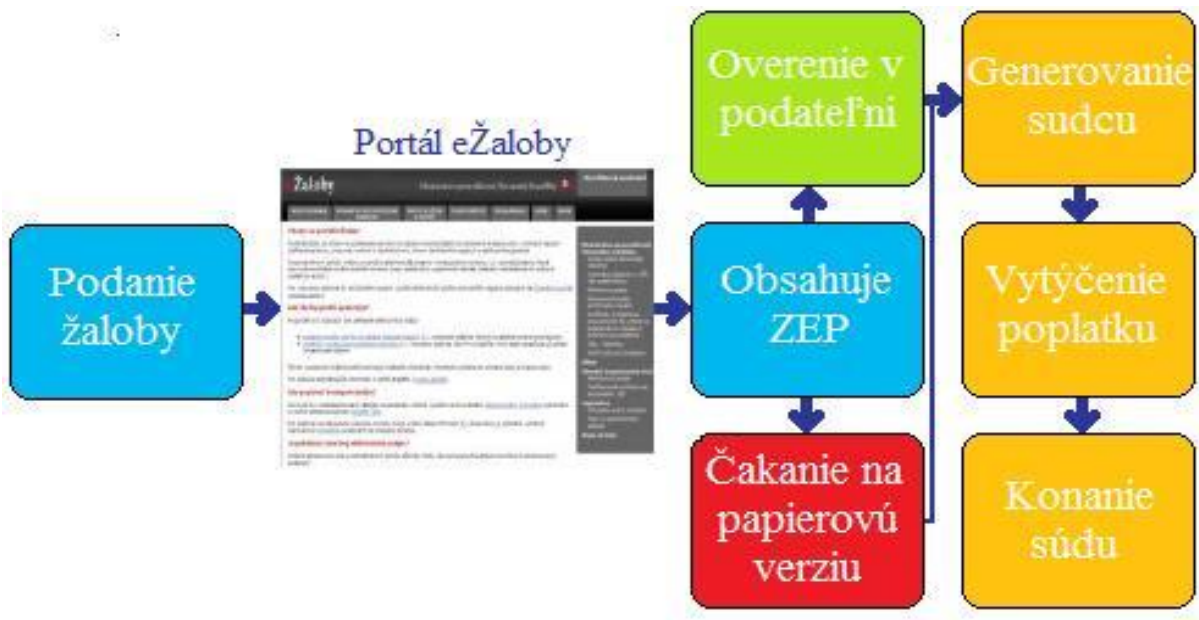

Obrázok: Schéma riešenia (Zdroj: Microsoft. [online]. Dostupné na internete:

<http://www.microsoft.com/slovakia/casestudies/mssr_anasoft.mspx>)

\section{Daňové riaditel'stvo}

Portál daňovej správy SR je výsledkom realizácie elektronickej verejnej a štátnej správy $\mathrm{v}$ podmienkach daňovej správy, pričom hlavným zámerom bolo vybudovanie jednotného vstupného bodu (jednej brány, t.j. portálu) pre elektronickú komunikáciu a pre poskytovanie elektronických služieb medzi daňovou správou a daňovými subjektmi, verejnost'ou, inými štátnymi orgánmi a organizáciami. Poskytovanie autorizovaných elektronických služieb je realizované v súlade s platnou legislatívou Slovenskej republiky. Využívanie týchto služieb je dostupné akejkol'vek fyzickej osobe, ktorá absolvuje jednotlivé kroky procesu registrácie a autorizácie. Pre využívanie služby elektronického podávania daňových dokumentov si subjekt vyberie jednu z dvoch možností elektronického doručovania písomností, ktoré mu v súlade s platnými legislatívnymi podmienkami ponúka daňová správa:

- Podanie písomností so zaručeným elektronickým podpisom. Odporúčanou možnost'ou z hl'adiska zvýšenia komfortu pri využívaní elektronických služieb a zachovania bezpečnosti komunikácie je obstaranie kvalifikovaného certifikátu pre zaručený elektronický podpis od akreditovanej certifikačnej 
autority. V súčasnosti poskytujú túto službu na území Slovenskej republiky viaceré akreditované certifikačné autority. Zaručený elektronický podpis je rovnoprávny vlastnoručnému podpisu a daňový subjekt nie je povinný správcovi dane doručovat' daňové písomnosti papierovou formou.

- Podanie písomností bez zaručeného elektronického podpisu.

Daňový subjekt, ktorý si zvolil možnost' elektronickej komunikácie so správcom dane s využitím zaručeného elektronického podpisu, je povinný si ho pred jeho prvým použitím priradit' do zoznamu certifikátov používatel'a. V prípade, že sa používatel' rozhodne neskôr doručovat' dokumenty bez zaručeného elektronického podpisu, uzavrie s daňovým úradom „Dohodu o spôsobe doručovania písomností doručovaných elektronickými prostriedkami, ktoré nebudú podpísané zaručeným elektronickým podpisom, uzavretú podl'a $\S 20$ ods.8 zákona č. 511/1992 Zb. v znení neskorších predpisov. [6]

Túto možnost' komunikácie (zaručeným elektronickým podpisom) s príslušným Daňovým úradom odporúčame hlavne pre tie organizácie resp. fyzické osoby, ktoré podávajú daňové dokumenty (daňové priznanie) za viac organizácii. Výhodou je, že jedným certifikátom môžete podpisovat' všetky daňové dokumenty bez ohl'adu na to, za ktorú spoločnost' na Daňovom úrade konáte. Ďalšou výhodou je, že služba funguje v režime online, určite ušetríte čas, peniaze a aj nervy. [7]

\section{Záver}

Môžeme konštatovat', že dnešný stav elektronického podpisu má pozitívny ale aj negatívny vplyv na situáciu v tejto krajine. Aj ked' v súčasnosti elektronický podpis nie je štandardne používaný vzhl'adom na jeho slabé rozšírenie, predpokladáme, že tieto problémy budú onedlho odstránene a príslušné orgány začnú napíňat’ hlavnú myšlienku elektronického podpisu.

\section{Literatúra}

[1] Ministerstvo financií Slovenskej republiky. Stratégia informatizácie spoločnosti na roky 2009 - 2013. 2009. [online]. Bratislava : Ministerstvo financií Slovenskej republiky, 2009.

Dostupné na internete:

<http://www.rokovania.sk/appl/material.nsf/0/B18E3E0D949E985EC125764F00487E 46/\$FILE/Zdroj.html\#_Toc235873046>.

[2] Colné konanie a vývoz tovarov cez internet. [online]. Dostupné na internete: $<$ http://www.euroinfo.gov.sk/index/go.php?id=1759>.

[3] Využitie ZEP - pri komunikácií s Katastrom nehnutel'nosti. [online] Dostupné na internete : <http://www.esignature.sk/elepodpis/2-ELEKTRONICKYPODPIS/27-Kataster-a-ZEP>.

[4] Elektronická komunikácia so súdom. [online].

Dostupné na internete : <http://www.esignature.sk/elepodpis/2-ELEKTRONICKYPODPIS/7-Sudy-a-ZEP>.

[5] Žalujte elektronicky. [online].

Dostupné na internete :

<http://www.microsoft.com/slovakia/casestudies/mssr_anasoft.mspx>. 
[6] Používatel'ská príručka pre Autorizované elektronické služby. [online]. Daňové riaditel'stvo Slovenskej republiky.

Dostupné na internete: $<$ https://www.drsr.sk/drsr/ur/doc/pouziv_prirucka.pdf $>$.

[7] Daňové priznanie - elektronicky pomocou ZEP. [online].

Dostupné na internete $:<\mathrm{http}: / / \mathrm{www}$.porada.sk/t73438-danove-priznanie-elektronickypomocou-zep.html>.

\section{Grantová podpora}

Článok je súčast'ou riešenia úlohy Data modeling $\mathrm{v}$ procese vzdelávania $\mathrm{v}$ počítačovom laboratóriu Katedry spojov - KEGA 036-017ŽU-4/2010 a Integrácia študentov so zdravotným postihom do edukačného procesu s dôrazom na unifikáciu prístupu $\mathrm{k}$ virtuálnej informačnej infraštruktúre a prostriedkom IKT - KEGA 386-017SPU-4/2010. 